\title{
Association with litter size of new polymorphisms on $E S R 1$ and $E S R 2$ genes in a Chinese-European pig line
}

\author{
Gloria MUÑOz ${ }^{\mathrm{a}}$, Cristina OviLO ${ }^{\mathrm{a}}$, Jordi EsTELLÉ ${ }^{\mathrm{b}}$, Luis Silió ${ }^{\mathrm{a} *}$, \\ Almudena FERNÁNDEZ ${ }^{\mathrm{a}}$, Carmen RODRIGUEZ ${ }^{\mathrm{a}}$ \\ ${ }^{a}$ Departamento de Mejora Genética Animal, SGIT-INIA, 28040 Madrid, Spain \\ ${ }^{\mathrm{b}}$ Departament de Ciència Animal i dels Aliments, UAB, 08193 Bellaterra, Spain
}

(Received 14 July 2006; accepted 31 October 2006)

\begin{abstract}
The objective of this study was to search for polymorphisms in the coding region of the estrogen receptors 1 and 2 (ESR 1 and ESR2) and to analyze the effects of these variants and the well known intronic ESR1 PvuII polymorphism on litter size in a Chinese-European pig line. We identified five silent single nucleotide polymorphisms (SNP) in the ESR1 cDNA: c.669T > C (exon 3), c.1227C > T (exon 5), c.1452C > T (exon 7), c.1665T > C and c.1755A $>$ G (exon 8). One pair of these SNP (c.1665T > C and c.1755A > G) co-segregated in the analyzed line, and the SNP c.669T > C showed the same segregation pattern as the $P v u$ II polymorphism. These polymorphisms were tested in this study, although the c.1452C $>$ T SNP within exon 7 was not analyzed due to its low informativeness. In the ESR2 cDNA, one missense SNP was found within exon 5, which caused an amino acid substitution in the coded protein: "c.949G > A (p.Val317Met)" and was tested on sow litter size. Information on 1622 litter records from 408 genotyped sows was analyzed to determine whether these SNP influenced the total number of piglets born (TNB) or the number of born alive (NBA). The polymorphisms ESR1: [PvuII; c.669T > C], ESR1: [c.1665T > C; c.1755A > G] and ESR2: c.949G > A showed no statistically significant association with litter size. However, the ESR1: c.1227T allele was significantly associated with TNB. The additive substitution effect was estimated to be 0.40 piglets born per litter $(P<0.03)$, and no dominance effects were observed. This SNP could be useful in assisted selection for litter size in some pig lines, as a new genetic marker in linkage disequilibrium with the causative mutation.
\end{abstract}

estrogen receptor genes / polymorphisms / pig / litter size

\section{INTRODUCTION}

Conventional selection for litter size in pig breeding schemes has traditionally been inefficient because of the low heritability and difficulties for intense

*Corresponding author: silio@inia.es 
selection of this sex-limited trait for which phenotypic measurement is only possible late in life [25]. Marker-assisted selection (MAS) has been proposed as a complementary tool to enhance the rate of genetic improvement of this kind of trait [16]. During the past two decades, the application of techniques of genetic evaluation based on mixed-model methodology on large datasets of pig reproductive records has been successful in achieving moderate genetic changes for prolificacy in dam lines $[19,21]$. The use of direct selection of some genes associated with reproductive traits has been recommended to achieve further genetic progress for litter size in pig breeding schemes [23]. However, the genetic tests recommended to the industry programs cannot detect the causative mutations (direct markers) but detect linked markers in a linkage disequilibrium population with these ones (LD markers). As a consequence, the potential extra genetic gains achieved from assisted selection should be lowered [3]. A paradigmatic case is the estrogen receptor 1 (ESR1), proposed as a major gene for prolificacy in 1996 by Rothschild et al. [24]. The reported association between a polymorphic $P v u I I$ restriction site in the ESR1 gene and litter size has been supported by subsequent studies [8,27,28], whereas no statistical association between this single nucleotide polymorphism (SNP) and prolificacy was detected in other populations $[5,6,20]$. A meta-analysis of 15 published association studies outlined the high and significant heterogeneity of the ESRI PvuII polymorphism effects estimated among studies performed in diverse pig populations [1]. This inconsistency among results could be attributed to sampling error but also to genotype by environment interaction, linkage, genetic background or population stratification.

Beyond the commercial application as LD marker of the intronic ESRI $P v u I I$ polymorphism, ESRI and ESR2 have a crucial role in the female biology of reproduction that justify further research on the association of other SNP with litter size. Estrogen is known for its role in the development and functioning of the female reproductive system. The primary mechanism of estrogen's action is via binding and modulation of activity of the estrogen receptors (ESR1 and ESR2), which are ligand-dependent nuclear transcription factors expressed at high levels in female tissues critical to reproduction, including the ovaries, uterus, cervix, mammary glands and pituitary gland. Although in vitro studies suggest that both ESR may play redundant roles, a dissimilar tissue distribution indicates otherwise [15], and their respective functions have been inferred from the use of specific ESRI and ESR2 knockout mouse models [2, 10, 26]. Korach et al. [9] and Krege et al. [14] generated and studied knockout mice lacking estrogen receptors 1 (1ERKO) and 2 (2ERKO). They reported complete infertility for the 1ERKO mice and fewer and smaller litters 
than wild-type mice for the 2ERKO mature females. These researches revealed that ESR1 is essential for female sexual differentiation, fertility and lactation and ESR2 is essential for normal ovulation efficiency. In pigs, ESR1 mRNA levels showed maximal expression at early pregnancy [13], and other studies suggested that the ESR2 gene is related to estrogenic functions such as maturation of the ovarian follicles as well as the growth and development of peri-implantation embryos $[12,29]$. In spite of its critical role in reproductive physiology, the ESR2 gene has scarcely been investigated as a candidate gene for litter size in pigs. We previously detected a polymorphism at an Hsp92II recognition site in the ESR2 gene in two Iberian pig populations [18]. No statistically significant association between this ESR2 SNP and litter size was found.

The objective of this research was to perform the first joint study of the porcine ESR 1 and ESR2 genes focused on the research of the polymorphisms located in the coding region of these two genes, and the evaluation of their respective effects on litter size traits in a composite Chinese-European pig line.

\section{MATERIALS AND METHODS}

\subsection{Animals}

The Chinese-European line of pigs used for this study was created in 1994 from 31 Meishan and 3 Jiaxing sows inseminated with 32 hyperprolific French Large White boars, and then selected for lean growth along nine generations [17]. We procured the total number of piglets born (TNB) and the number of born alive (NBA) recorded in 5932 litters farrowed from 2397 sows in four breeding nuclei located in France and Spain. A subset of 408 genotyped sows with records from 1622 litters was used in the association study. A summary of all the available information is presented in Table I. Moreover, six animals from the Iberian, Large White and Meishan breeds and two Spanish Wild boars were analyzed to look for new polymorphism in the ESR2 cDNA.

\subsection{Isolation and sequencing of porcine $E S R 1$ and $E S R 2$ cDNA}

Ovary samples from two Chinese-European sows were collected on liquid $\mathrm{N}_{2}$ and stored at $-80{ }^{\circ} \mathrm{C}$. Total RNA was extracted with the Tri Reagent (Sigma Aldrich Chemie, Madrid, Spain). Reverse transcription (RT) was performed with the Superscript II kit (Invitrogen, Life Technologies, Barcelona, Spain) and random hexamers. 
Table I. Number of animals, litters, mean, and standard deviation (SD) of the analyzed litter records.

\begin{tabular}{ll}
\cline { 2 - 2 } Animals in pedigree & 2742 \\
Sows with records & 2397 \\
Herd-year-season & 50 \\
Litters & $5932 *$ \\
NBA, number born alive & $12.76(\mathrm{SD}=3.49)$ \\
* TNB, total number born & $13.97(\mathrm{SD}=3.75)$ \\
\cline { 2 - 2 } 1622 litters from & \\
\hline
\end{tabular}

Four overlapping ESR1 cDNA fragments encompassing exons 1-8 were amplified with primers designed from the available nucleotide sequences of the coding region and the 5' untranslated region (UTR) of the porcine ESRI gene (Genbank accession numbers: Z37167 and AF034972). The polymerase chain reactions (PCR) were performed in $25 \mu \mathrm{L}$ volumes containing $2 \mu \mathrm{L}$ of cDNA, standard PCR buffer (75 mM Tris-HCl pH 9.0, $50 \mathrm{mM} \mathrm{KCl,} 20 \mathrm{mM}$ $\left.\left(\mathrm{NH}_{4}\right)_{2} \mathrm{SO}_{4}\right)$, and concentrations of $\mathrm{MgCl}_{2}, \mathrm{dNTP}$, primers and Tth polymerase (Biotools, Madrid, Spain) optimized for each amplified fragment. Amplification conditions were $94{ }^{\circ} \mathrm{C}$ for $3-5$ min, followed by 40 cycles of $94{ }^{\circ} \mathrm{C}(30 \mathrm{~s})$, different annealing temperatures for each primer pair $(30 \mathrm{~s})$ and $72{ }^{\circ} \mathrm{C}(45 \mathrm{~s})$, with a final extension step of $8-10 \mathrm{~min}$ at $72{ }^{\circ} \mathrm{C}$. The PCR reactions were performed on a PTC-100 thermocycler (MJ Research, Watertown, MA, USA). The RT-PCR products were sequenced twice with different primers using the Dye Terminator Cycle Sequencing kit in an ABI 310 automatic sequencer (Applied Biosystems, Warrington, UK) and aligned with the MegAlign software (Winstar program package). Primer sequences, annealing temperatures and amplicon sizes are given in Table II. The assembled fragments form a $1885 \mathrm{bp}$ sequence that covers the 5'UTR and exons 1-8 (1788 bp).

A similar procedure was used for sequencing the coding region of the ESR2 gene. Four other overlapping cDNA fragments were amplified with primers designed from the pig ESR2 cDNA sequence (AF164957), covering exons 1-8. Technical details can be found in Muñoz et al. [18]. The assembled fragments cover $1561 \mathrm{bp}$ of the ESR2 gene coding region (1581 bp), between the positions 17 and 1571. This nearly complete ESR2 cDNA was re-sequenced in six pigs from the Iberian, Large White and Meishan breeds and in two Spanish Wild boars. 
Table II. Primer sequences, annealing temperatures, and amplicon sizes used for sequencing and genotyping the ESRl gene.

\begin{tabular}{lllll}
\hline Name & Primer sequences & $\begin{array}{l}\text { Annealing } \\
\text { Temp. }\left({ }^{\circ} \mathrm{C}\right)\end{array}$ & $\begin{array}{l}\text { Size } \\
(\mathrm{bp})\end{array}$ & Exon \\
\hline ESRa-F & 5'-TAACCGCGGGCTGTGCTCTTCTTC-3' & 63 & 510 & 5'UTR-Exon1 \\
ESRa-R & 5'-CCGCTCGGCTCATTCTCCAGGTAA-3' & & & \\
ESRb-F & 5'-GCCGCAGCTCTCGCCCTTCCT-3' & 63 & 501 & Exons 1-4 \\
ESRb-R & 5'-ACCGCTTCATTCCTGCCCTCTCCA-3' & & & \\
ESRc-F & 5'-GGGGGATACGGAAAGACC-3' & 57 & 551 & Exons 4-6 \\
ESRc-R & 5'-ACGGAAGCGAGATGATGTAGC-3' & & & \\
ESRd-F & 5'-TGTGTCGAGGGAATGGTGGAG-3' & 58 & 540 & Exons 6-8 \\
ESRd-R & 5'-TCAGATTGTGGTGGGGAAGTT-3' & & & \\
EX5F & 5'-CCTCCATGATCAAGTGCATCTTCT-3' & 55.5 & 138 & Exon 5 \\
EX5R & 5'-CAGCCAGGTCACTTACTGTCCAG-3' & & & \\
EX5pyr & 5'-TTTGCTCCTAACTTGCT-3' & & & Exon 5 \\
EX7F & 5'-GGAGTGTACACGTTTCTGTCC-3' & 55 & 184 & Exon 7 \\
EX7R & 5'-TCATGTGCCTGAAGTGAGAC-3' & & & \multirow{2}{*}{ Exon 7 } \\
EX7pyr & 5'-TCCTGGACAAGATCACA-3' & & & \\
\hline
\end{tabular}

\subsection{SNP identification and genotyping}

The alignment of the obtained ESRI cDNA sequences and the reference sequence Z37167 showed three SNP within exons 3, 5 and 7, respectively and two SNP within exon 8. The polymorphisms detected in exons 5 and 7 were genotyped on genomic DNA samples by pyrosequencing and the first polymorphism detected in exon 8 by PCR-RFLP AvaI [4], respectively. Pyrosequencing was performed in a PSQ96 system (Pyrosequencing AB, Uppsala, Sweden). PCR primer sequences (EX5F-EX5R and EX7F-EX7R) and two pyrosequencing primers (EX5pyr and EX7pyr) were designed and are listed in Table II. The previously described intronic $P v u I I$ polymorphism was genotyped on genomic DNA samples to identify alleles $A$ and $B$ following the published PCR-RFLP protocol [27]. The PvuII polymorphism and the SNP detected in exon 3 cosegregated as well as both SNP in exon 8.

The alignment of the obtained ESR 2 cDNA sequences from diverse genetic origins and the reference sequence AF164957 revealed two SNP within exons 2 and 5, respectively. The SNP detected in exon 5 introduces a polymorphic Hsp92II restriction site, and was genotyped on genomic DNA samples by a PCR-RFLP protocol previously described [18]. 


\subsection{Statistical analysis}

The following univariate repeatability animal model was used to estimate genetic parameters for NBA and TNB:

$$
\mathbf{y}=\mathbf{X} \beta+\mathbf{Z}_{1} \mathbf{u}+\mathbf{Z}_{2} \mathbf{p}+\mathbf{e}
$$

where $\mathbf{y}$ included the 5932 litter size records (NBA and TNB), $\beta$ the systematic effects of parity order (6 levels), genetic line of the litter's sire (ChineseEuropean or Landrace) and herd-year-season, and $\mathbf{u}$ and $\mathbf{p}$ the polygenic and permanent environmental random effects, respectively. Heritabilities $\left(h^{2}=\right.$ $\left.\sigma_{u}^{2} / \sigma_{y}^{2}\right)$ and coefficients of permanent environmental effects $\left(p^{2}=\sigma_{p}^{2} / \sigma_{y}^{2}\right)$ estimated from these data were $0.13 \pm 0.05$ and $0.09 \pm 0.04$ for NBA, and $0.14 \pm$ 0.06 and $0.11 \pm 0.05$ for TNB, respectively. Similar models were used for the association analyses fitting in $\beta$ the ESR1 or ESR2 SNP genotypic effects, and assuming the estimates of variance components as true values. The additive effect $(a)$ of each SNP was measured as half difference between the estimated effects of homozygous genotypes, and the dominance effect $(d)$ as the deviation of the heterozygous genotype effect from the mean effect of the homozygous genotypes. Computations for all these analyses were performed using the VCE-5 software [11].

\section{RESULTS}

In ESR1 in samples from Chinese-European pigs, we detected five silent SNP within exons 3 (c.669T > C), 5 (c.1227C > T), $7($ c.1452C > T) and 8 (c.1665T > C and c.1755A > G). In the ESR2 in samples from Iberian and Chinese-European pigs, one silent SNP was detected within exon 2 (c.486A > G) in samples from the Meishan breed, and moreover one missense SNP within exon 5 (c.949G > A).

A total number of 408 Chinese-European sows with litter size records, 19 of their sires and 78 of their dams, were genotyped for the above quoted SNP identified in both genes. The distribution of the numbers of sows and litters by genotype and the allelic frequencies are provided in Table III. The ESRI $P v u I I$ and c.669T $>$ C polymorphisms co-segregated in this line in the combinations $[A$; c.669T] and $[B ; \mathrm{c} .669 \mathrm{C}]$. The c. $1665 \mathrm{~T}>\mathrm{C}$ and c. $1755 \mathrm{~A}>\mathrm{G}$ ESRI allelic variants co-segregated in the combinations c. [1665C; $1755 \mathrm{G}]$ and c.[1665T; 1755A]. No co-segregation was observed between the c.1227C $>\mathrm{T}$ or c.1452C $>\mathrm{T}$ polymorphisms within exons 5 and 7 , respectively and other SNP identified in the ESRI gene. Finally, the c.1452C > T polymorphism 
Table III. Number of sows $(n)$ and litters $(N)$ by genotype, and allelic frequencies of ESR1 and ESR2 genes.

\begin{tabular}{|c|c|c|c|c|c|c|c|}
\hline \multicolumn{6}{|c|}{ ESR1 } & \multicolumn{2}{|c|}{ ESR2 } \\
\hline$\overline{[P \vee u \mathrm{II} ; \text { c.669T >C }]}$ & \multicolumn{2}{|c|}{ c. $1227 \mathrm{C}>\mathrm{T}$} & \multicolumn{3}{|c|}{$[\mathrm{c} .1665 \mathrm{~T}>\mathrm{C} ; \mathrm{c} .1755 \mathrm{~A}>\mathrm{G}]$} & \multicolumn{2}{|c|}{ c. $949 \mathrm{G}>\mathrm{A}$} \\
\hline Genotype $n \quad N$ & Genotype & $n \quad N$ & Genotype & $n$ & $N$ & Genotype & $n \quad N$ \\
\hline$[A ; \mathrm{T}][A ; \mathrm{T}] \quad 56 \quad 222$ & $\mathrm{CC}$ & 116433 & {$[\mathrm{C} ; \mathrm{G}][\mathrm{C} ; \mathrm{G}]$} & 200 & 774 & AA & 25 \\
\hline$[A ; \mathrm{T}][B ; \mathrm{C}] 180699$ & CT & 208868 & {$[\mathrm{C} ; \mathrm{G}][\mathrm{T} ; \mathrm{A}]$} & 166 & 661 & AG & 155575 \\
\hline$[B ; \mathrm{C}][B ; \mathrm{C}] 167683$ & TT & 81308 & {$[\mathrm{~T} ; \mathrm{A}][\mathrm{T} ; \mathrm{A}]$} & 39 & 174 & GG & 228955 \\
\hline Allelic frequencies & & & & & & & \\
\hline$[A ; \mathrm{T}] \quad 0.36$ & $\mathrm{C}$ & 0.54 & {$[C ; G]$} & 0 . & & A & 0.25 \\
\hline$[B ; C]$ & $\mathrm{T}$ & 0.46 & {$[\mathrm{~T} ; \mathrm{A}]$} & & & G & 0.75 \\
\hline
\end{tabular}

was discarded for the association study due to its low informativeness in the Chinese-European pig line, for which the allele frequencies were c.1452C (0.97) and c.1452T (0.03).

We failed to identify unambiguously all the segregating ESRl haplotypes combining the intronic PvuII SNP and the five silent SNP detected within exons 3, 5, 7 and 8, because of the lack of some parental genotypes. As a consequence, we could not perform a joint association study based on ESRI intragenic haplotypes, and the analyses of the effects of ESRI alleles on litter size were performed separately for the two pairs $([P v u \mathrm{II}$; c.669T $>\mathrm{C}]$ and $[\mathrm{c} .1665 \mathrm{~T}>\mathrm{C}$; c.1755A $>\mathrm{G}$ ]) of co-segregating polymorphisms, and the c. $1227 \mathrm{C}>\mathrm{T}$ SNP.

The results of the association analyses are presented in Table IV. Estimates of the effect on NBA and TNB of [PvuII $A$; c.669T][PvuII $A ; c .669 \mathrm{~T}]$ and [PvuII $A$; c.669T][PvuII $B$; c.669C] genotypes, measured as deviations from the $[P v u \mathrm{II} B ; \mathrm{c} .669 \mathrm{C}][P v u \mathrm{II} B$; c.669C] genotype, were very small, and no significant additive and dominance effects were detected for these genotypes, which include the ESRl PvuII SNP. Also, no significant effects on litter size were found for the [c.1665C; c. $1755 \mathrm{G}][\mathrm{c} .1665 \mathrm{C}$; c.1755G] and [c.1665C; c.1755G][c.1665T; c.1755A] genotypes (Tab. IV). Nevertheless, the c.1227T allele was significantly associated with a higher total number of piglets born. The additive substitution effect was estimated to be 0.40 piglets per litter $(P<0.03)$, and no dominance effects were observed. Moreover, there was a consistent favorable effect of the c.1227T allele on NBA ( 0.25 piglets $)$, without statistical significance $(P<0.14)$.

The c.949G $>$ A polymorphism is the only ESR2 SNP detected in the composite Chinese-European line (Tab. III). This change causes an amino acid substitution in the coded protein (p.Val317Met), but the estimates of the effect on litter size of the genotypes c.949AA and c.949AG, measured as 
G. Muñoz et al.

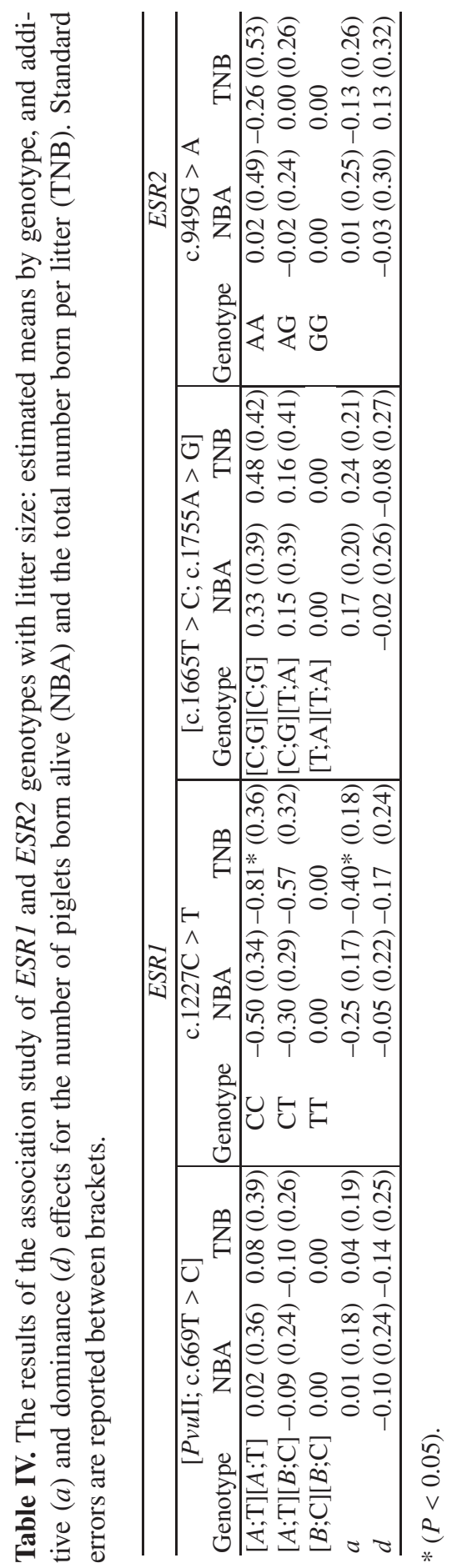


deviations from the genotype c.949GG, were not significantly different from zero (Tab. IV).

\section{DISCUSSION}

First reports regarding the ESR1 PvuII SNP effects on litter size [24, 27] stated the favorable additive effect of the $B$ allele to be the largest in pig lines of Meishan origin (1.4 piglets per copy) and intermediate in Large White based lines (0.4 piglets per copy). However, Rohrer et al. [22] failed to detect an effect of the ESR I PvuII SNP on ovulation rate and uterine capacity in a multigeneration Meishan $\times$ White composite experimental population. Also, Gibson et al. [6] found no detectable association of this SNP with sow productivity traits in a Meishan $\times$ Large White $\mathrm{F}_{2}$ intercross. In a recent study performed on records from 1250 Czech Large White sows and 3600 litters, the $B$ allele was found to be disadvantageous to the $A$ allele for prolificacy [7]. The results of the present study also failed to confirm significant effects of the ESRI PvuII SNP on litter size in a composite Chinese-European line. It can also be outlined that this negative result cannot be attributed to a low sample size of the experiment. The number of animals and records of each genotypic class allows the detection of additive effects of at least $0.4-0.5$ piglets per litter (Tabs. III and IV).

The main result of this paper is the estimation of a positive effect on litter size of a new detected SNP (c.1227C > T) located in the coding region of the ESRl gene, with a favorable effect of the c.1227T allele $(0.4$ piglets per copy) on the total number born per litter. However, this polymorphism is a silent change, and therefore is not likely to be the causative mutation of a positive effect on litter size. One feasible explanation could be that this SNP is in linkage disequilibrium with the causative mutation, as it probably occurs in other pig populations with the ESRI PvuII polymorphism. All the results obtained in this study concerning the ESRI gene allow us to discard the coding region of this gene as the possible location of the causative mutation. The c. $1227 \mathrm{C}>\mathrm{T}$ polymorphism could be useful as a LD marker to select boars in the breeding nucleus of this composite line among full-sib males with the same estimated breeding value for litter size. However, the effective implementation of a LD-MAS program based on this SNP requires careful measurement of its possible phenotypic effects on growth and carcass traits, continuous monitoring and re-evaluation of its effects on litter size [3].

Whereas all the SNP detected in the coding region of the ESRl gene are silent polymorphisms, the c.949G > A SNP identified within exon 5 of the 
ESR2 gene is a non-conservative substitution. This alteration involves the replacement of the non-polar amino acid, valine, by the polar sulfur containing amino acid, methionine, which could modify the secondary and tertiary structure of the protein due to the different ability of these amino acids to form hydrogen and di-sulfide bonds. The potential deleterious effect of the mutation p.Val317Met located in the ligand-binding domain is suggested by its conserved amino acid position among some mammalian species (Rattus norvergicus, Genbank accession number: Q62986, Mus musculus: O08537 and Bos taurus: Q9XSB5). Although all these data support the possible biological relevance of this amino acid change, we found no detectable association between the ESR2 c. $949 \mathrm{G}>\mathrm{A}$ SNP and the litter size traits, and this polymorphism can be discarded as a direct or LD marker in this composite Chinese-European pig line.

\section{ACKNOWLEDGEMENTS}

Financial support was provided by Spanish MCYT grant FIT01-0000-2001027. We are grateful to Gene+, especially to Fernando Flamarique, Michel Sourdioux and Christian Gasnier, for supplying data and blood samples. $\mathrm{J}$. Estellé is a recipient of a FPU PhD grant from Spanish MEC.

\section{REFERENCES}

[1] Alfonso L., Use of meta-analysis to combine candidate gene association studies: application to study the relationship between the ESR PuvII polymorphism and sow litter size, Genet. Sel. Evol. 37 (2005) 417-435.

[2] Couse J.F., Korach K.S., Environmental hormones: The scientific basis of endocrine disruption, Ann. N.Y. Acad. Sci. 948 (2001) 1-8.

[3] Dekkers J.C.M., Commercial application of marker- and gene-assisted selection in livestock: Strategies and lessons, J. Anim. Sci. 82 (E. Suppl.) (2004) E313E328.

[4] Drogemuller C., Thieven U., Harlizius B., An AvaI and MspII polymorphism at the porcine estrogen receptor (ESR) gene, Anim. Genet. 28 (1997) 59.

[5] Drogemuller C., Hamann H., Distl O., Candidate gene markers for litter size in different German pig lines, J. Anim. Sci. 79 (2001) 2565-2570.

[6] Gibson J.P., Jiang Z.H., Robinson J.A.B., Archibald A.L., Haley C.S., No detectable association of the ESR PvuII mutation with sow productivity in a Meishan $\times$ Large White $F_{2}$ population, Anim. Genet. 33 (2002) 448-450.

[7] Goliasova E., Wolf J., Impact of the ESR gene on litter size and production traits in Czech Large White pigs, Anim. Genet. 35 (2004) 293-297. 
[8] Horogh G., Zsolnai A., Komiosi I., Nyiri A., Anton I., Fesus L., Oestrogen receptor genotypes and litter size in Hungarian Large White pigs, J. Anim. Breed. Genet. 122 (2005) 56-61.

[9] Korach K.S., Couse J.F., Curtis S.W., Washburn T.F., Lindzey J., Kimbro K.S., Eddy E.M., Migliaccio S., Snedeker S.M., Lubahn D.B., Schomberg D.W., Smith E.P., Estrogen receptor gene disruption: molecular characterization and experimental and clinical phenotypes, discussion 186-8 Review, Recent Prog. Horm. Res. 51 (1996) 159-86.

[10] Korach K.S., Emmen J.M.A., Walker V.R., Hewitt S.C., Yates M., Hall J.M., Swope D.L., Harrell J.C., Couse J.F., Update on animal models developed for analyses of estrogen receptor biological activity, J. Steroid Biochem. 86 (2003) 387-391.

[11] Kovăc M., Groeneveld E., García-Cortés L.A., VCE-5, a package for the estimation of dispersion parameters, in: Proceedings of the 7th World Congress on Genetics Applied to Livestock Production, Montpellier, 19-23 August 2002, Vol. 33, pp. 741-742.

[12] Kowalski A.A., Graddy L.G., Vale-Cruz D.S., Choi I., Katzenellenbogen B.S., Simmen F.A., Simmen R.C., Molecular cloning of porcine estrogen receptorbeta complementary DNAs and developmental expression in preimplantation embryos, Biol. Reprod. 66 (2002) 760-769.

[13] Kowalski A.A., Vale-Cruz D.S., Simmen F.A., Simmen R.C., Uterine androgen receptors: Roles in estrogen-mediated gene expression and DNA synthesis, Biol. Reprod. 70 (2004) 1349-1357.

[14] Krege J.H., Hodgin J.B., Couse J.F., Enmark E., Warner M., Mahler J.F., Sar M., Korach K.S., Gustafsson J.A., Smithies O., Generation and reproductive phenotypes of mice lacking estrogen receptor beta, Proc. Nat. Acad. Sci. USA, 95 (1998) 15677-15682.

[15] Kuiper G.G.J.M., Carlsson B., Grandien K., Enmark E., Haggblad J., Nilsson S., Gustafson J.A., Comparison of the ligand binding specificity and transcript tissue distribution of estrogen receptors alpha and beta, Endocrinology 138 (1997) 863-870.

[16] Lande R., Thompson R., Efficiency of marker-assisted selection in the improvement of quantitative traits, Genetics 124 (1990) 743-756.

[17] Milan D., Demeure O., Laval G., Iannuccelli N., Genet C., Bonnet M., Burgaud G., Riquet J., Gasnier C., Bidanel J.P., Identification de régions du génome répondant à la sélection dans une lignée porcine sino-européenne : la Tai zumu, Journ. Recher. Porc. 35 (2003) 309-316.

[18] Muñoz G., Ovilo C., Amills M., Rodríguez C., Mapping of the porcine oestrogen receptor 2 gene and association study with litter size in Iberian pigs, Anim. Genet. 35 (2004) 242-244.

[19] Noguera J.L., Varona L., Babot D., Estany J., Multivariate analysis of litter size for multiple parities with production traits in pigs: II. Response to selection for litter size and correlated response to production traits, J. Anim. Sci. 80 (2002) 2548-2555. 
[20] Noguera J.L., Varona L., Gomez-Raya L., Sánchez A., Babot D., Estany J., Messer L.A., Rothschild M., Pérez-Enciso M., Estrogen receptor polymorphism in Landrace pigs and its association with litter size performance, Livest. Prod. Sci. 82 (2003) 53-59.

[21] Petit G., Runavot J.P., Gruand J., Legault C., Évaluation en race pure et en croisement de la lignée hyperprolifique Large White dans un réseau d'élevages de multiplication et de production, Journ. Recher. Porc. 20 (1988) 309-314.

[22] Rohrer G.A., Ford J.J., Wise T.H., Vallet J.L., Christenson R.K., Identification of quantitative trait loci affecting female reproductive traits in a multigeneration Meishan-White composite swine population, J. Anim. Sci. 77 (1999) 1385-1391.

[23] Rothschild M.F., Porcine genomics delivers new tools and results: This little piggy did more than just go to market, Genet. Res. Camb. 83 (2004) 1-6.

[24] Rothschild M.F., Bidanel J.P., Biology and genetics of reproduction, in: Rothschild M.F. and Ruvinsky A. (Eds.), The Genetics of the Pig, CAB International, Wallingford, United Kingdom, 1998, pp. 313-343.

[25] Rothschild M.F., Jacobson C., Vaske D., Tuggle C., Wang L., Short T., Eckardt G., Sasaki S., Vincent A., McLaren D., Southwood O., van der Steen H., Mileham A., Plastow G., The estrogen receptor locus is associated with a major gene influencing litter size in pigs, Proc. Natl. Acad. Sci. USA 93 (1996) 201-205.

[26] Schomberg D.W., Couse J.F., Mukherjee A., Lubahn D.B., Sar M., Mayo K.E., Korach K.S., Targeted disruption of the estrogen receptor-alpha gene in female mice: Characterization of ovarian responses, Endocrinology 140 (1999) 2733-2744.

[27] Short T.H., Rothschild M.F., Southwood O.I., McLaren D.G., de Vries A., van der Steen H., Eckardt G.R., Tuggle C.K., Helm J., Vaske D.A., Mileham A.J., Plastow G.S., Effect of the estrogen receptor locus on reproduction and production traits in four commercial pig lines, J. Anim. Sci. 75 (1997) 3138-3142.

[28] van Rens B.T.T.M., de Groot P.N., van der Lende T., The effect of estrogen receptor genotype on litter size and placental traits at term in F2 crossbred gilts, Theriogenology 57 (2002) 1635-1649.

[29] Ying C.W., Hsu W.L., Hong W.F., Cheng W.T.K., Yang Y.C., Estrogen receptor is expressed in pig embryos during preimplantation development, Mol. Reprod. Develop. 55 (2000) 83-88. 